\title{
THE TENSION BETWEEN THE AUTONOMY OF REASON AND NATURE IN HEGEL'S PHILOSOPHY OF NATURE
}

\section{A TENSÃO ENTRE A AUTONOMIA DA RAZÃO E NATUREZA NA FILOSOFIA DA NATUREZA DE HEGEL}

\author{
V. Metin Demir ${ }^{1}$
}

Recebido em: 05/2020

Aprovado em: 11/2020

\begin{abstract}
This article discusses the relationship between the externality of nature and the autonomy of reason, one of the most vexed problems in Hegel's philosophy. Simply, it focuses on the question of how the compatibility of the logical structure of reason and factual reality is solved in Hegelian system. It is asserted here that Hegel finds the answers given before him in modern philosophy of nature inadequate, so he refuses both realist and idealist approaches. For him, nature is neither wholly compatible nor distinct from reason. Since he repudiates the two options, asking whether Hegel's philosophy of nature is a priori style or not becomes irrelevant. After reviewing the literature, a new interpretation beyond this dichotomy is suggested. On the basis of an analysis of the first pages of Philosophy of Nature I will show that, according to Hegel, nature and metaphysics are two different language games: the essential issue is a problem of translation. Although Idea serves as a metalanguage holding together these two language games, no exact transition is possible. Keywords: philosophy of nature, empirical sciences, naturalism, Idea in externality, impotence of Nature
\end{abstract}

Resumo: Este artigo discute a relação entre externalidade da natureza e autonomia da razão, um dos mais controversos problemas na filosofia de Hegel. Dito de modo simples, este artigo concentra-se na questão de como a compatibilidade da estrutura lógica da razão e da realidade factual é solucionada no sistema hegeliano. Afirma-se, aqui, que Hegel considera inadequadas as respostas dadas antes dele na filosofia da natureza moderna, e que, portanto, ele recusa tanto a abordagem realista quanto a idealista. Para ele, a natureza não é nem totalmente compatível, nem totalmente distinta da razão. Uma vez que ele repudia as duas opiniões, perguntar se a filosofia da natureza de Hegel é um modelo a priori ou não se torna irrelevante. Após a revisão da literatura, uma nova interpretação para além dessa dicotomia é sugerida. Com base na análise das primeiras páginas da Filosofia da Natureza, vou mostrar que, de acordo com Hegel, natureza e metafísica são dois jogos de linguagem diferentes: a questão essencial é um problema de tradução. Embora a Ideia sirva como uma metalinguagem que mantém unidas esses dois jogos de linguagem, nenhuma transição exata é possível.

Palavras-chave: filosofia da natureza, ciências empíricas, naturalismo, ideia em externalidade, impotência da natureza

\footnotetext{
${ }^{1}$ Dr. Faculty Member at Istanbul Sehir University, Philosophy Department, Turkey.
} 


\section{Hegel's Disclaiming of both Realist and Idealist Conception of Nature}

Scientific description of nature entails a certain degree of realism, which must suppose that nature stands outside of us and we can represent this external nature by means of sensory data and some opaque logico-mathematical tools. What Hegel opposes is this naïve conception of science. The fact that the sensory data is prior in obtaining the knowledge of nature does not mean that it has a priority over other types of knowledge. It is possible to say that the distinction between "what comes prior" and "what has priority" distinguishes Hegel's idea of nature from empiricist-naturalist tradition:

In this conjunction, the prevailing fundamental misunderstanding is that the natural principle, or the starting point in the natural development or the history of an individual in the process of self-formation, is regarded as the truth and conceptually the first. Intuition or being are no doubt first in the order of nature, or are the condition for the concept, but they are not for all that the unconditioned in and for itself; on the contrary, in the concept their reality is sublated and, consequently, so is also the reflective shine that they had of being the conditioning reality (Hegel, 2010, s. 519). ${ }^{2}$

Hegel does not deny the importance of naturalist (natural principle) or empiricist approaches based on sense certainty, in obtaining the knowledge of nature. Yet what he tries to address is the following question: Do these natural principles or empirical evidences have absolute validity? To put it differently, are these calculable, perceptual-experimental evidences in itself explanatory or not? If the answer is yes, then there could be no philosophy of nature other than empirical sciences. After all, according to general opinion, only empirical natural science can say the last word about nature, and by that philosophy of nature can only be seen as a bygone occupation. The rise of philosophy of sciences and correspondingly the decline of philosophy of nature can be seen a result of this opinion. Hegel starts his study of philosophy of nature with this opinion and states: "It can be said that in our time [...] that the Philosophy of Nature in particular is in considerable disfavor" (Hegel, 2004, § $244 \mathrm{Z}, 1$ ). The possibility to develop a philosophy of nature distinct from philosophy of science, which directly follows empirically oriented sciences (Winfield, 2017, 5), lies in the subtle distinction mentioned above.

\footnotetext{
2 "Ein hauptsächlicher Mißverstand, welcher hierbei obwaltet, ist, als ob das natürliche Prinzip oder der Anfang, von dem in der natürlichen Entwicklung oder in der Geschichte des sich bildenden Individuums ausgegangen wird, das Wahre und im Begriffe Erste sei. Anschauung oder Sein sind wohl der Natur nach das Erste oder die Bedingung für den Begriff, aber sie sind darum nicht das an und für sich Unbedingte; im Begriffe hebt sich vielmehr ihre Realität und damit zugleich der Schein auf, den sie als das bedingende Reelle hatten”.
} 
Hegel did not intend to produce a philosophy of science in the style of Popper, Kuhn or Lakatos. He rather tells what nature is, and he proposes metaphysical account of the structure of nature (Wandschneider, 2013). Thus, in order to revive the philosophy of nature, Hegel makes the natural sciences based on empirical data as his target and problematizes their authority in understanding of nature.

For Hegel, empirical sense data comes first in the knowledge of nature however; this type of knowledge is not an absolute verification principle (Beiser, 2005, 53). The roots of this claim can be traced back to Aristotle, who makes a distinction between 'prior by nature' and 'prior in relation to us':

Things are prior and more familiar in two ways; for it is not the same to be prior by nature $[\pi \rho o ́ \tau \varepsilon \rho o v ~ \tau \tilde{\eta} \iota ~ \varphi v ́ \sigma \varepsilon 1]$ and prior in relation to us $[\pi \rho o ̀ \varsigma ~ \dot{\eta} \mu \tilde{\alpha} \varsigma$

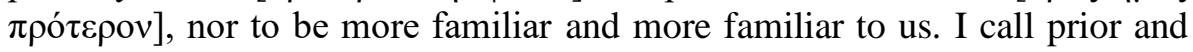
more familiar in relation to us what is nearer to perception, prior and more familiar simpliciter what is further away. What is most universal is furthest away, and the particulars are nearest; and these are opposite to each other (Aristotle, 1991a, 70b34-72a5, 3).

This Aristotelian interpretation that puts universal and particular into opposite sites, might cause a misconception that "what is by nature" and "what is in relation to us" are wholly different areas of investigation. Hence, this may lead us to imagine that on the one side there are natural scientists occupied with empirical data and on the other side philosophers of nature, tarrying with the a priori abstract realm. However, for Hegel, this misconception is an awful kind of prejudice:

It is only an ill-minded prejudice [zu den üblen Vorurteilen] to assume that philosophy stands antithetically opposed to any sensible appreciation of experience [...] These shapes [of consciousness] are themselves recognized [anerkannt] by philosophy, and even justified by it. Rather than opposing them, the thinking mind [der denkende Sinn] steeps itself in their basic import; it learns from them and grows strong, just as it does from the great intuitions of nature, history, and art; for this solid content, once it has been thought, is the speculative Idea itself (Hegel, 2004, 5). ${ }^{3}$

Nevertheless, the impression that Hegel's philosophy of nature has a priori style, which drift away from empirical natural sciences was highly prevalent in the beginning of twentieth

\footnotetext{
3 “Es gehört zu den üblen Vorurteilen, als ob sie sich im Gegensatz befände gegen eine sinnige Erfahrungskenntnis, [...] diese Gestalten werden von der Philosophie anerkannt, ja selbst gerechtfertigt; der denkende Sinn vertieft sich vielmehr in deren Gehalt, lernt und bekräftigt sich an ihnen wie an den großen Anschauungen der Natur, der Geschichte und der Kunst; denn dieser gediegene Inhalt ist, sofern er gedacht wird, die spekulative Idee selbst”.
} 
century. One of the most famous examples of this is Karl Popper's claim that Hegel "draws real physical rabbits out of purely metaphysical silk-hats" and what he did is just an oracular philosophy (Popper, 1963, 25). Likewise, another influential philosopher at the beginning of twentieth century Benedetto Croce, claims that Hegel's philosophy of nature is an example of false science and this part of his system is dead, so it could be discarded (Croce, 1969).

Indeed, if Hegel suggests a philosophy of nature outside and beyond scientific progress, these accusations are somewhat justified. However, when the distinction between "what comes first to us", that is, what comes first in the research process and "what comes first by nature" or what comes first in the explanation is correctly understood, relationship between the philosophy of nature and empirical sciences in Hegel would become clearer. Is the philosophy of nature a separate field of research disconnected from science or is it a regulatory field like philosophy of science, that only clarifies the conceptual tools of science, the forms of argumentation, the limits of scientific claims? Hegel answers this question as follows:

In the first place, we find the Philosophy of Nature in a peculiar relationship to natural science in general, to physics, natural history, and physiology; it is itself physics, but rational physics. It is at this point that we have to grasp what the Philosophy of Nature is, [...] The Philosophy of Nature may perhaps be regarded prima facie as a new science, this is certainly correct in one sense, but in another sense it is not. For it is ancient, as ancient as any study of Nature at all; it is not distinct from the latter and it is, in fact, older than physics; Aristotelian physics, for example, is far more a Philosophy of Nature than it is physics. It is only in modern times that the two has been separated (Hegel, 2004, Z, 2).

In modern times, the identity of scientific research and philosophy of nature has been destroyed, so that drawing a dividing line between empirical natural sciences based on empirical-sensory evidence and the philosophy based on the study of pure concepts became possible. Hegel partially accepts this modern distinction by affirming that science and philosophy two has different ways of comprehension. Hegel writes:

Physics and natural history are called empirical sciences par excellence, and they profess to belong entirely to the sphere of perception and experience, and in this way to be opposed to the Philosophy of Nature, i.e. to a knowledge of Nature from thought. The fact is, however, that the principal charge to be brought against physics is that it contains much more thought than it admits and is aware of, [...] Physics and the Philosophy of Nature, therefore, are not distinguished from each other as perception and thought, but only by the kind and manner of their thought [die Art und Weise des Denkens] they are both a thinking apprehension of Nature (Hegel, 2004, Z, 3). 
Hence, making a distinction between experimental sciences such as physics and philosophy of nature that is based on concepts independent of experiment is a misconception. Since, for Hegel, physics is not just based on empirical observation and experiment, but it also contains metaphysics, even if physicist are not aware of this (Duhem, 1991). ${ }^{4}$ Moreover, Hegel insists on the idea that perception and concept cannot be isolated from each other. He states, "what is intuited must also be thought" (Hegel, 2004, § 246 Z, 12). Just as empirical sciences are not free from conceptual load, philosophy is not an a priori conceptual research far from the sciences. ${ }^{5}$ Conceiving the intuition and concepts separately also forms the ground of another basic distinction, that is, the separation of subjectivity and objectivity (Kant, 1999, A 835/B863, 693). ${ }^{6}$ The idea that there are two sources of knowledge, on the one side sensory data coming from objects and on the other side our concepts that we dress on the representation of the object, is the source of a discussion in modern philosophy known as the objective knowledge of nature. Therefore, the division between intuition and concept leading to the division of subjectivity and objectivity is one of the major dilemmas of the modern idea of nature, in Hegel's view:

The theoretical approach begins with the arrest of appetite, is disinterested, lets things exist and go on just as they are; with this attitude to Nature, we have straightway established a duality of object and subject and their separation, something here and something yonder. Our intention, however, is rather to grasp, to comprehend Nature, to make her ours, so that she is not something alien and yonder. Here, then, comes the difficulty: How do we, as subjects, come into contact with objects? If we venture to bridge this gulf and mislead ourselves along that line and so think this Nature, we make Nature, which is an Other than we are, into an Other than she is. Both theoretical approaches are also directly opposed to each other: we transform things into universals, or make them our own, and yet as natural objects they are supposed to have a free, self-subsistent being (Hegel, 2004, § $246 \mathrm{Z}, 8$ ).

If, from the very beginning, we assume the distinction between nature (i.e. sensibleobject-referent) and reason (i.e. concept, subject, sense) there would be two orientations that research can go: realism or idealism. For realism, finite things exist as they are and we can

\footnotetext{
${ }^{4}$ Hegel's accusation of physicist because of unconsciously using metaphysical categories is directed to Newtonian physics, which is supposed to avoid any kind of metaphysical hypothesis. For more elaborate criticism in contemporary philosophy of science on this point see: Duhem, 1991.

${ }^{5}$ Allison Stone proposes that Hegel's natural philosophy is rationalist, robustly a priorist. "According to this robust a priorism, the place of scientific claims in the system is temporary and interpretative" (Stone, 2005, 27). In this article, such kind of a prorist approachs are rejected.

${ }^{6}$ For example, Kant clearly divides reason and empirical and he states this separation as such: "By reason, however, I mean here the whole higher cognitive power, and therefore still contrast what is rational and what is empirical." Kant, CPR, A 835/B863, s. 693.
} 
know them in themselves through our experience. In opposition to that view, subjective idealism claims that subject imposes its universal forms on things, and the nature that we know is a "nature for us" not the nature in itself. Hegel regards both views as abstractly one-sided positions, because one is sticking to empirical singulars (as in empiricism and realism) while the other is sticking to universal (as in idealism and rationalism).

Hegel never finds the empiricist version of realism reasonable. Of course, while doing scientific research, our own considerations should be excluded from the examination and the object should be examined as it is. However, the problem is to assume that the sensible part in the experimental material contains no additions (Westphal, 2009). ${ }^{7}$

In the theoretical approach to Nature $(a)$ the first point is that we stand back from natural objects, leaving them as they are and adjusting ourselves to them. Here, we start from our sense-knowledge of Nature. However, if physics were based solely on perceptions, and perceptions were nothing more than the evidence of the senses, then the physical act would consist only in seeing, hearing, smelling, etc., and animals, too, would in this way be physicists (Hegel, 2004, § 246 Z, 7).

Here, Hegel sarcastically criticizes the attitude of the realist approach towards nature and he rejects the idea that one can reach the knowledge of nature directly through experiment and observation. He points out that the concepts, utilized by realist scientists in natural explanations, such as "force", "matter", "energy", "law" are not just subjective plugins, rather than objective necessities (Hegel, 2004, § 246 Z, 10). No scientific claim can be made without these objective, imperceptible, and conceptual relations. Hence, the error of realist is overlooking the space of reason within what is intuited, by identifying human's form of universal/scientific knowledge from animal's sensational form.

However, Hegel unexpectedly criticizes (subjective) idealism as well. In addition to refusing the idea that finite beings exist as they are, he also rejects the idea that the representation of the world is just a production of our minds. He writes:

Of a metaphysics prevalent today which maintains that we cannot know things because they are absolutely shut to us, it might be said that not even the animals are so stupid as these metaphysicians; for they go after things, seize and consume them (Hegel, 2004, § $246 \mathrm{Z}, 10$ ).

\footnotetext{
7 The thesis of Westphal, which claims that Hegel's method is a phenomenological method, seems reasonable. According to him, the phenomenological method makes explicit the objective properties of the interrelationship of the phenomena. Since these objective features among and within the phenomena are not in the strict sense perceptible, they are conceptual and the concepts form the structure of nature (Westphal, 2009).
} 
Contrary to realism, idealism asserts, "we create nature, we do it other than itself", but Hegel situate idealism on the other side of duality. Just as, against empiricist-realism Hegel says that "if relying on sense-data is sufficient for science, then animals can be physicist" (Hegel, 2004, § 246 Z, 7), this time, he also caricaturizes idealism by saying that "[if] we cannot know things because they are absolutely shut to us, it might be said that not even the animals are so stupid as these metaphysicians; for they go after things, seize and consume them" (Hegel, $2004, \S 246 \mathrm{Z}$, 9). If the world were only in my head, apart from the sensible objects, then the world would have to appear completely alien to the mind. Therefore, supposedly devoid of reason, animals' efforts in this unreasonable world have to be seen in vain, which is just ridiculous. In short, for Hegel idealism is a one-sided approach just as realism. Diverging from these alternatives, Hegel's philosophy of nature pursues to create a broader understanding that aims to overcome the one-sidedness of both idealism, based on the universal and necessary a priori laws of reason, and empirical-realism based on only empirical experiments and observations.

\section{Did Hegel Follow the Science or His Own Logic?}

One of the most essential debate among Hegel scholars is that whether Hegelian philosophy of nature is an a priorist, metaphysical approach or is it an a posteriorist antimetaphysical style, which follows empirical sciences of his age and designs his philosophy of nature in accordance with the results of these sciences.

According to many commentators, Hegel's philosophy of nature is the weakest part of his system for the reason that metaphysical natural philosophy had to expire after the historical victory of empirical natural sciences. Indeed, this part of Hegel's system has been so overlooked that, as Petry puts it, Hegel's philosophy of nature has almost never been studied until 1970s. (Petry, 1993; Perty, 1998). However, what is interesting is that Hegel consider himself as a natural scientist and presents himself likewise to the reader when he published his first major work. On the cover of the first edition of Phenomenology of Spirit in 1807, Hegel gives himself this title, "Professor of Philosophy in Jena University, the Counselor of the Ducal Mineralogy Society and the member of other Scientific Societies." "The reader is surprised to learn that the book on Geist the he is about to read is by an author claiming to be both philosopher and mineralogist" (Verene, 1998, 209). Indeed, Hegel had attended a field research in Gottingen 
and Harz Mountains as a member Westphalian Society for Natural Research to which he has been elected on August 1, 1804. Hegel's biography shows us that he was an enthusiastic science literate (Harris, 1993, 31; Pinkard, 2000, 186). According to generally accepted opinion, Hegel had predominantly occupied with political and metaphysical issues and his interest in natural sciences was only limited (Kolb, 1991, 91; Taylor, 1975, 351). ${ }^{8}$ However, research shows that a great deal of Hegel's library was consisting of the scientific manuscripts of his age (Engelhardt, 1972; Mense, 1993; Bronger, 1993; Neuser, 1993). Moreover, the Philosophy of Nature section of Hegel's Encyclopedia shows that he closely follows almost all ongoing scientific discussions of his own era. This also indicates that Hegel is a very sensitive philosopher toward empirical sciences. Now, relying on these biographical evidences, can we claim that Hegel is a philosopher who follows scientific developments in the empiricist-realist line?

Most Hegel scholars considers his philosophy of nature has an a priori, rationalist structure, rather than empirical. For them, Hegel grounds on the framework he builds in Logic, and melts down all the scientific studies of his age into his own logical pot, so natural sciences here serve only a means to demonstrate metaphysics in the example of reality. For those who see Hegelian metaphysics, in essence, as a category theory, that investigates the possible types of discourse on all intelligible things, metaphysics designs for comprehending all determination of thinking. Hence, nature must be seen just a totality dependent on these determinations. Natural sciences teach nothing to metaphysics; on the contrary, they just follow metaphysics. Many important commentators of Hegel such as; Charles Taylor (1975), ${ }^{9}$ Allison Stone (2005), Bernd Braßel (2004), Edward Halper (2005), Renate Washner (1996), Wolfgang Neuser (2017), Dieter Wanschneider (1992) favor this type of reading.

According to another group of scholars, Hegel affirms the scientific views of his age without any prejudice and classifies his categories of natural philosophy according to these scientific results. Hence, metaphysics is informed by natural sciences and follows the order of them, that is, it has an a posteriori character. Nature is not an extension of thought but its radical other.

In this second line of interpretation, the emphasis moves on to the determination of the actual reality, rather than the metaphysical categories in the epistemic framework. This group

\footnotetext{
${ }^{8}$ Charles Taylor also writes "Hegel's philosophy of nature was a somewhat more derivative work." (Taylor, 1975, 351).

${ }^{9}$ [The philosophy of nature] "presupposes what has been proven in the Logic, and also what has been shown by natural science and shows how one reflects the other" (Taylor, 1975, 352).
} 
highlights that the phenomena should not be organized by an external act of synthesis, as in Kant's approach, but rather one should let things to present themselves as they are [die Sache Selbst], so that the synthesis of Concept would always affirms the actuality of phenomena. For these scholars, "if Hegel grounds his metaphysics on such formalism, then he could not manage to naturalize his thought" (Breidbach, 2004). "Thus, the Philosophy of Nature is not the embodiment or instantiation of or concretizing of logical forms, because what was distinctive about that form of logic is precisely what is not found in nature" (Maker, 2005, 19). "Scientific studies must firstly be proved empirically then their feasibility for the Concept must be shown" (Ferrini, 2004). Many of Hegelian commentators such as Michael J. Petry, (2001, 200) Arthur Findlay (1958), Gerd Buchdahl (1972), Errol E. Harris (1974), Terry Pinkard (2012, 19), Olaf Breidbach (1982), Frederik Beiser (2005, 57) William Maker (2005), Susan Hahn (2007) basically participate this second line of reading, despite some minor differences of their approaches. Two different lines of interpretations can roughly be schematized as this:

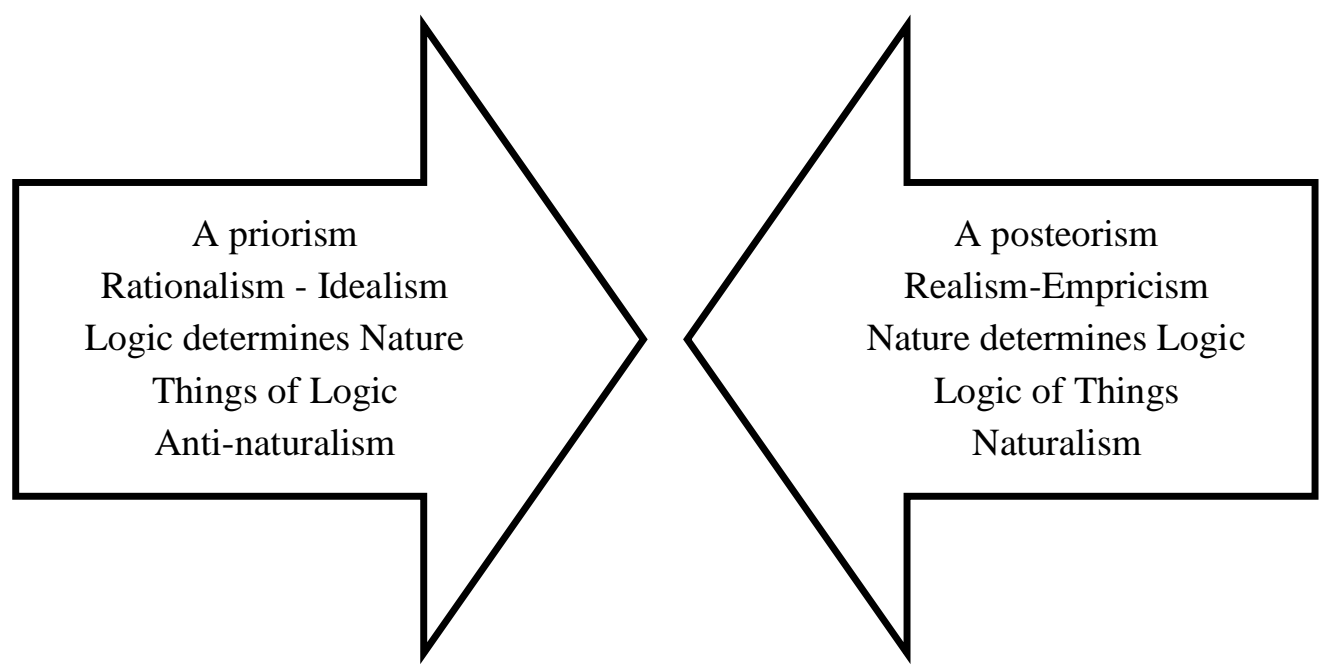

Figure 1 Two Camps on The Interpretation of Hegel's Philosophy of Nature

There is a vexing dilemma here; either one should accept a kind of metaphysical idealism that presupposes an isomorphism between thought and its other, by denying radical the otherness of nature for the sake of the systematic unity of metaphysical Idea, or one have to relinquish the idea of the autonomy of reason, by accepting nature as a something given to thought, which renders nature alien to thought.

Neither approaches will be completely accepted here. As mentioned above, Hegel repudiates the distinction between a priori and a posteriori or between sense and thought. Thus, 
compelling Hegel to choose one of these two options amounts to missing his speculative way of thinking. As John Burbidge demonstrated, natural philosophy does not directly imitate Logic. For example, the "Chemism" chapter of Logic and the "Chemistry" section of Philosophy of Nature have different compartments and contents (Burbidge, 2002). Still, the fact that logic and philosophy of nature have separate contents and forms does not mean they are separate from each other.

As Burbidge maintains, under the "Chemism" title of his Logic, Hegel uses chemistry as an analog for thought and examines how things acquire their singularities through universal laws in a relational manner. However, in the "Chemistry" section of the Philosophy of Nature, he examines chemical phenomena such as galvanism, combustion, acid-base reactions etc. Well, are these two disconnected? In the first four paragraphs of the eleven-paragraph length chapter that he devotes to "Chemistry" in his Philosophy of Nature, Hegel reviews the previous development of his system and logically analyzes how transition to chemistry is dialectically accomplished. In the next five paragraphs, he exhaustively rehearses scientifically approved chemical facts. In the last two remaining paragraphs, he integrates the logical, developmental structure with scientific facts, and he finally moves on to the next step, that is, biology. Thus, progress proceeds here through a mutual determination of "thought-nature-thought". Thought seeks out the structures that correspond to itself in nature and creates a new template by combining the results of natural science with its own initial considerations. Neither the logical structure of thought nor the scientific evidence is unquestionable here. New experimental evidence might create new complications for the systematic account (Burbidge, 2006). Burbidge summarizes his approach as this:

\footnotetext{
Schematically, it seems to me, it happens this way: thought thinks about what would be quite other than thought - its most general and basic characteristics. Then it looks to experience to see what in fact fits that description. Next it sees what happens in that realm once we distinguish its various moments. We analyze and abstract the phenomena that match our original projections, and we notice the significance of what happens. Finally we take our original thought and incorporate into it the results that in fact have emerged. We create a speculative synthesis, and from this we can generate a new concept that integrates the various elements into a single thought. Once we have that thought, we then turn back to nature to see what fits this new template (Burbidge, 2006, 181).
}

Thus, in Hegel's system, nature is neither alien to the structure of thought nor completely identical with it. Speculative synthesis, as the identity of identity and difference, attempts to 
think of logic and nature together without eliminating the difference between them. If we return to the question of Aristotle, we could say that the philosopher of nature knows neither only Logos, nor only matter. On the contrary, the philosopher grasps these two with their identity in difference. For this very reason, Hegel says, "philosophy of nature is a comprehending study" (Hegel, 1991, § 246, 6). ${ }^{10}$ The Hegelian natural philosophy, then, does not resort to either an a priori, universalist model of explanation, nor an a posteriori model of explanation based entirely on empirical evidence. Therefore, it is fair to say that Hegel did not follow either idealistrationalist or empiricist-realist traditions.

\section{Hegel's Proposal: The Science and Metaphysics are Two Different Language Games}

While Hegel criticized idealism for breaking away from singular objects in the world, for alienating from living bodies, for constraining itself merely to universals in human thought, he also criticized realism because of its alienation of universal essence of human knowledge. "The former contains a universal without determinateness, the latter an individuality without a universal" (Hegel, 1991, § 246 Z, 12). Hegel seeks to produce a new synthesis by critically reevaluating both idealist and realist methods of studies of nature [Naturbetrachtungsweise]. With this synthesis he tries to show the idea that physics without metaphysics is impossible and vice versa, very much once Kant argued: "intuition without concepts are blind, concept without intuition are empty" (Kant, 1998, p. 193). For Hegel, physics alone is not scientific enough, because the universals of physics, i.e. physical laws are independent of their instantiations, so it remains abstract. Moreover, in physical sciences, the properties of the single object are not considered in integrity, rather each properties of object are explained by different disciplines such as; optics, chemistry, geology, morphology etc. Each of these disciplines has their own concepts independently, thus in the explanation of physical sciences distinct, isolated universals compose a singular object, without any internal necessity (Hegel, 1991, § 246 Z, 10). Hegelian metaphysics of nature attempts to overcome this abstractness of sciences and tries to restore this defect.

What is intuited must also be thought, the isolated parts must be brought back by thought to simple universality; this thought unity is the Notion, which contains the specific differences, but as an immanent self-moving unity. The determinations of philosophical universality are not indifferent; it is the

10 "die Naturphilosophie begreifende Betrachtung ist." 
universality which fulfils itself, and which, in its diamantine identity [diamantenen Identität], also contains difference (Hegel, 1991, § $246 \mathrm{Z}, 12) .{ }^{11}$

Thus, the principle of "identity of identity and difference" must again put into practice, without clinging to the distinction between universal and singular, objective and subjective, thought and intuition, but at the same time without reducing differences of them, as in idealist and realist versions. From the beginning, Hegel rejects the division, subsists in the Aristotelian and Kantian traditions, between a priori-intelligible order [scientia-theoria] and a posteriori sensible order [empiria-historia]. Thus, he frees himself from being stuck in Humean fork, which bifurcates between the logical field of the Idea and the relations of facts in the field of reality (Rauch, 1989, 150). Instead, a priori and a posteriori mutually determines each other (Westphal, 2008, 297). ${ }^{12}$

Philosophy of nature and physics shares the same objects, but have different ways of thinking. For this reason, the philosophy of nature need to be all ears to the material coming from empirical sciences, but the whole legitimacy of it is not this empirical material (Hegel, 1991, § $246 \mathrm{R}, 6) .{ }^{13}$ While physics classically is experimental examination, calculation and classification of nature, philosophy of nature is reconsideration of this classification, regarding particular-universal relationship, with respect to the Concept. It can be said that, while physics is a struggle for "saving the phenomena" (Duhem, 2015), to ensure the internal consistency of the experiments and observations, the philosophy of nature is a struggle for "saving the reason" to ensure the internal consistency of the Concept (Falkenburg, 2005). ${ }^{14}$ Hegel describe this difference as such:

What is now called physics was formerly called natural philosophy, and it is also a theoretical, and indeed a thinking consideration of Nature; but, on the one hand, it does not start from determinations which are external to Nature, like those ends already mentioned; and secondly, it is directed to a knowledge

\footnotetext{
11 "Der Philosophischen Allgemeinheit sind die Bestimmungen nich gleichgültig, sie ist die sich selbst erfüllende Allgemeinheit, die in ihrer diamantenen Identität zugleich den Unterschied in sich enthält" (GW, 24, s. 1184).

12 Westphal claims, in his article, that metaphysics is basically semantics. If the semantic refers to observer subjects' interpretative capacity, this would bring Hegel's philosophy closer to subjective idealism, which seems to me not an appropriate reading.

13 "Not only must philosophy be in agreement with our empirical knowledge of Nature, but the origin and formation of the Philosophy of Nature presupposes and is conditioned by empirical physics. However, the course of a science's origin and the preliminaries of its construction are one thing, while the science itself is another. In the latter, the former can no longer appear as the foundation of the science; here, the foundation must be the necessity of the Notion."

14 Birgitte Falkenburg proposes that the Kantian and Newtonian line has an extensional Fregean logic and semantics, yet the Leibnizian-Hegelian line has an entirely different intentional semantics. While Newton's physics and Kant's intuition theory are looking for the criteria on which that external could corresponds, conceptual idealist like, Leibniz and Hegel took the integrity of reason as the criteria.
} 
of the universal aspect of Nature, a universal which is also determined within itself -directed to a knowledge of forces, laws and genera, whose content must not be a simple aggregate, but arranged in orders and classes, must present itself as an organism. As the Philosophy of Nature is a comprehending [begreifend] treatment, it has as its object the same universal, but explicitly, and it considers this universal in its own immanent necessity in accordance with the self-determination of the Notion (Hegel, 1991, § 246, 6).

Thus, while empirical sciences are trying to give name, classify and conceptualize the phenomena that emerge in their fields, the philosophy of nature reprocesses the material provided by empirical sciences in accordance with the structure of logical intelligibility. The philosophy of nature is not an examination of nature through observation, but an explanation of these observations in a systematic unity and logical necessity. Philosophy, of course, owes its development to empirical sciences, but it does not follow sciences exactly, instead it gives its (a priori) form to the material of these sciences, thus it gets its legitimacy from systematic coherency and the logical necessity [die Bewährung der Notwendigkeit] (Hegel, 1991, § 12, 37). It is worth to notice, by saying "to give an a priori form" does not mean grounding the scientific data in respect to a previously prepared logical table, as Kant did in his philosophy of nature. Rather, it means metaphysics must review the findings of natural science by translating them to the language of the Concept. Hence, the philosophy of nature is obliged to translate the material provided by empirical sciences into the language of the Concept. "Just as Homer says about certain things that they have two names, one in the language of Gods, and the other on the tongues of us men" (Hegel, 1991, 5). Logical idea is the language of pure thought, or to put it in a more Hegelian jargon, it is the language in which the eternal essence of God is expressed [die Darstellung Gottes], before the creation of nature and finite spirits (Hegel, 2010, 29). ${ }^{15}$

The Philosophy of Nature takes up the material which physics has prepared for it empirically, at the point to which physics has brought it, and reconstitutes it, so that experience is not its final warrant and base. Physics must therefore work into the hands of philosophy, in order that the latter may translate into the Notion the abstract universal transmitted to it, by showing how this universal, as an intrinsically necessary whole, proceeds from the Notion (Hegel, 2004, § 246, Z, 10).

Therefore, from one perspective, philosophy of nature and sciences have the same objects, from another they do not. Both are identical in terms of dealing with natural

\footnotetext{
15 "daß dieser Inhalt die Darstellung Gottes ist, wie er in seinem ewigen Wesen vor der Erschaffung der Natur und eines endlichen Geistes ist.”
} 
phenomena. However, while empirical sciences regard nature as ready-made or given material and always consider experimental results and mathematical proofs as the highest validity criterion, philosophy of nature does not regard nature as ready-made outside of us, but gets its criterion of validity from systematic, conceptual unity, not from experiment and mathematics. Whereas in the language of empirical sciences only empirically verifiable facts are meaningful, in metaphysical language only those facts with conceptual form are meaningful. ${ }^{16}$ Empirical sciences and the philosophy of nature are not two sciences working on two different subjects, but two different language games on the same subject. ${ }^{17}$ These two languages are established on two different metaphysical views and two different understanding of universality.

What distinguishes the Philosophy of Nature from physics is, more precisely, the kind of metaphysics used by them both; for metaphysics is nothing else but the entire range of the universal determinations of thought, as it were, the diamond net into which everything is brought and thereby first made intelligible. Every educated consciousness has its metaphysics, an instinctive way of thinking, the absolute power within us of which we become master only when we make it in tum the object of our knowledge. Philosophy in general has, as philosophy, other categories than those of the ordinary consciousness: all education [Bildung] reduces to the distinction of categories. All revolutions, in the sciences no less than in world history, $[\ldots]$ has changed its categories, [for] comprehending itself more truly, more deeply, more intimately, and more in unity with itself (Hegel, 2004, § 246, Z, 11 [italics are mine]).

In Hegel's philosophy of nature, nature is considered not as a given, an absolute reality reached by experimental data, but as a totality that finds its actuality and validity in metaphysics. Every phenomenon and conceptual framework that we encounter in natural sciences is transformed relocated and translated into the language of metaphysics (Hegel, 1991, $\S 9,33)^{18}$ and made possible to take their place in the crystal structure of intelligibility.

\section{Translation Problems between Two Languages}

Is it possible to translate science into metaphysics? Is it possible to explain every natural phenomenon in accordance with the Conceptual structure? Are each of the scientific

\footnotetext{
${ }^{16}$ For a nuanced account of the relation between empirical facts and metaphysical concepts see: (Ferrini 2004b).

${ }^{17}$ I use here "language-game" in Wittgensteinian sense. In his book, Philosophical Investigation, Wittgenstein uses the concept language-game, in order to refer the idea that any concept in a language has its meaning depending on the context of the family-resemblance rules of a certain language-game.

18 "Der Unterschied bezieht sich insofern allein auf diese Veränderung der Kategorien"
} 
developments peacefully and submissively ready to take their place in the self-assured structure of natural philosophy, taking into account that empirical sciences constantly reveal new phenomena and thus constantly force all the previous conventional conceptualizations to change, also given that these sciences unceasingly transforming (perhaps progressing) in themselves? Even as natural sciences draw their strength from constantly destroying established patterns of thinking by finding new phenomena, could the dialectical framework of the Concept completely embrace this uncontrollable power of natural sciences? Can allegedly the admirable crystal structure of intelligibility (i.e. Logic) cope with the ever-updated data of natural sciences?

This is the point where the tension between the natural sciences and autonomy of reason peaks. While the philosopher intends to put the results of sciences into his own crystal metaphysical network, the sciences come up again with a new challenge. Thanks to this challenge, empirical sciences gain a tactical advantage over the philosophy of nature, and tend to declare the weakness of metaphysics over sciences. Nevertheless, Hegel accepts this attack and reverses it, as he always does. According to him, the fact that philosophy becomes breathless in the face of the dazzling speed of sciences, is not the poverty of metaphysics, but instead the impotence of nature [Ohnmacht der Natur] (Hegel, 2004, § 250, 23). Hegel sees the failure of metaphysics in pursuit of the dizzying plurality of the materials provided by the sciences, not as a shame of metaphysics, but rather as the weakness of nature. Natural sciences are obliged to explain all the phenomena revealed by observation and experiment because its absolute guarantor is empirical evidence (Hegel, 2004, § 270, Z, 82). ${ }^{19}$ However, philosophy has no duty to explain all the richness of life.

This impotence of Nature sets limits to philosophy and it is quite improper to expect the Notion to comprehend-or as it is said, construe or deduce-these contingent products of Nature. [...] Nature everywhere blurs the essential limits of species and genera by intermediate and defective forms, which continually furnish counter examples to every fixed distinction (Hegel, 2004, $\S 250$, Z., 23).

\footnotetext{
19 "Philosophy has to start from the Notion, and even if it does not assert much, we must be content with this. The Philosophy of Nature is in error when it wants to account for every phenomenon; this is what happens in the finite sciences, which try to trace everything back to general conceptions, the hypotheses. In these sciences, the sole verification of the hypothesis lies in the empirical element and consequently everything must be explained. But what is known through the Notion is clear by itself and stands firm; and philosophy need not feel any embarrassment about this, even if all phenomena are not yet explained. I have therefore set down here only the rudiments of a rational procedure in the comprehension of the mathematical and mechanical laws of Nature as this free realm of measures. This standpoint, I know, is ignored by professional astronomers; but a time will come when this science will require for its satisfaction the philosophical Notion."
} 
Thus, for Hegel, the sciences and philosophy of nature are in part compatible but in part incompatible. They are compatible, because in order to do science one has to believe that nature has an intelligible structure. They are incompatible because there will always remain some random and unexplained phenomena in nature. Conceptual language and actual reality cannot coincide with each other in every instance. Indeed, "Nature confronts us as a riddle and a problem" (Hegel, 2004, § 250, 23-24). Hegel says, "the being of Nature does not accord with its Notion; rather is Nature the unresolved contradiction" (Hegel, 2004, $\S 248,17) .{ }^{20}$ Contradiction in nature remains in general, between crystal structure of Concept and multiplicity of experimental data, but in particular, there are plenty of contradictions, such as, determinacy-contingency, individual-species, nature-nurture, entropy-telenomy, mind-brain, on which endless discussions carry on in the scientific literature. The source of the idea of the impotence of nature lies right here, since according to Hegel finding Idea totally in nature is impossible. While, nature exhibits a rational structure suitable for Idea, when it presents a reasonable conceptual necessity, where universal laws explain individual phenomena, it always confronts us with new contingencies and developments. For this reason, Hegel describes nature as Idea in its otherness. While logical Idea become satisfied when it dialectically sublates all the contradictions at the end of Logic, Idea let itself go with the flow of the multiplicity of external determinations in nature. Thus, when we find rationality in nature, what we find would be a transformed rationality, that is, Idea in its otherness. Therefore, there must be an immanent Idea in nature, but this Idea does not cover every phenomenon emerging in nature.

The contradiction of the Idea, arising from the fact that, as Nature, it is external to itself, is more precisely this: that on the one hand there is the necessity of its forms which is generated by the Notion, and their rational determination in the organic totality; while on the other hand, there is their indifferent contingency and indeterminable irregularity (Hegel, 2004, § 250, 23).

In this externality, the determinations of the Notion have the show of an indifferent subsistence and isolation [Vereinzelung] in regard to each other, and the Notion, therefore, is present only as something inward. Consequently, Nature exhibits no freedom in its existence, but only necessity and contingency [Natur zeigt daher in ihrem Dasein keine Freiheit, sondern Notwendigkeit und Zufälligkeit] (Hegel, 2004, § 248, 17).

\footnotetext{
20 "aber wie sie ist, entspricht ihr Sein ihrem Begriffe nicht; sie ist vielmehr der unaufgelöste Widerspruch".
} 
For Hegel, while the essence of Concept is freedom and necessity (Hegel, 2010, 511) what we see in nature is necessity and contingency, ${ }^{21}$ which renders nature "an unresolved contraction". It is possible to conclude that there are certain laws, regularities and patterns by which nature has an intelligible structure, however, since necessity and contingency coexist in it, nature never fully reconcile with Idea. There is a reason in nature but this reason is not that of Idea, which can fully comprehend itself by sublating all otherness. However, "reason in nature" is determined externally and contingently, as Schelling puts it as petrified intelligence [versteinerte Intelligenz], or what Hegel says Idea in its externality [sich äußerliche Idee] (Hegel, 2004, § $247 \mathrm{Z}, 14){ }^{22}$

Hence, Logic and Nature do not exactly coincide. Hegel never reduces "the logic of things" to "the things of logic", as Marx may accuse. ${ }^{23}$ Although rationalist conception of nature sees a kind of isomorphism between thought and being, post-Kantian German idealism did not maintain this hypothesis. For them, nature needs reason to be intelligible, yet there exists only an asymptotic correspondence relation between nature and reason. This means that translation between two languages is possible, but only to some extent. Since Hegel rejects any immediately given object independent of reason, natural objects have to be categorized on the criteria of intelligibility. Therefore, "Hegel's philosophy conceives of nature as made up of phenomenal structures of increasing degrees of complexity, to which quite distinct conceptual structures applied" (Falkenburg, 2005, 98).

Hence, by describing nature not as a given, ready-made reality, Hegel differs from both realism and empiricism. He also differs from subjective idealism, because nature is not the creation of our thoughts or categories. He also does not agree with Schelling, who proposes that nature is absolute or unconditioned (Schelling, 2004, 13). Contrary to Schelling, nature is conditioned with respect to Idea that is the absolute. Thus, for Hegel, "the metaphysics of Nature [...] is to be the Idea in the form of otherness, and this implies that existence of Nature is essentially an ideality, since it exists relatively, nature is essentially related to a First" (Hegel,

\footnotetext{
${ }^{21}$ Famous French biologicist and thinker Jacques Monod, in his influencial book, Necessity and Contigency, debunks every type of dialectics in the operation of genetic structure, and claims that the operation of nature is anti-Hegelian. Interestingly the title of his book sounds so Hegelian and he describes nature in the same way as Hegel, as the realm of necessity and contingency. For his claims see: Jacques Monod (1972), Chance and Necessity, trans. Austryn Wainhouse, New York: Vintage Books, p. 110.

22 "die Metaphysik der Natur, als die wesentliche Gedankenbestimmtheit ihres Unterschiedes, diese ist, daß die Natur die Idee in ihrem Andersseyn ist." GW, 24, s. 1188.

${ }^{23}$ Marx sees whole Hegelian philosophy as a reduction of everything into logic and labels his whole system as applied metaphysics. "All things being reduced to a logical category, and every movement, every act of production, to method, it follows naturally that every aggregate of products and production, of objects and of movement, can be reduced to a form of applied metaphysics. What Hegel has done for religion, law, etc. (Marx, 2000, 218).
} 
$2004, \S 247,15)$. This definition implies that a philosophy of nature is impossible without first having a metaphysical conception. This is why Hegel always attempts to conceive nature in a system and so he built a system of nature after completing a metaphysical logic. ${ }^{24}$ This interpretation might illuminate one of the most problematic, cryptic sentences in the Hegelian system:

[...] the intuiting Idea is Nature. [...] The absolute freedom of the Idea, [...] in the absolute truth of itself, it resolves to release out of itself into freedom the moment of its particularity or of the initial determining and otherness, [i.e.,] the immediate Idea as its reflection, a or itself as Nature (Hegel, 1991, $\S 244,307) .^{25}$

the idea freely discharges itself, absolutely certain of itself and internally at rest. On account of this freedom, the form of its determinateness is just as absolutely free: the externality of space and time absolutely existing for itself without subjectivity (Hegel, 2010, 753). ${ }^{26}$

The misleading anthropomorphic language here may cause to get an impression as if there is a conscious Idea and he decides to create nature. However, Idea does not mean a conscious being but the "movement of grasping itself in its other." When this movement applied to the pure thought $[$ Logic] itself, the result would be the same movement, that is, Logic displays the same jest to itself and recognize itself in the form of its other, namely, recognizing itself within the realm of time and space. Thus, philosophy of nature amounts to the process of reason's looking for itself in nature. "To observe [nature] is to congeal the concept in being and consequently to seek the concept only as a being" (Hyppolite, 2000, 234). The Intuited Idea grasping within the things provides the explanation of nature. Therefore, the basic occupation of philosophy of nature is to rationalize what is seemingly irrational in nature, (Quante, 2008) that is, to eliminate the otherness of nature, to translate a foreign language into the language of logic.

\footnotetext{
${ }^{24}$ The unity of Concept and reality is justified according to the structure of Idea. However, nature and the Concept can not coincide because of the impotence of nature and so nature and the concept differentiates. Nature contains absolute Idea in itself and Idea reveals itself in nature but this revelation is not a full exposition. Absolute's exposition (Enthüllung) is also a withdrawal (Verhüllung). Klaus J. Schmidt, "Die Logische Struktur der Natur", Sich in Freiheit entlassen Natur und Idee bei Hegel, ss. 31-63.

25 "Die absolute Freiheit der Idee aber ist, daß sie nicht bloß ins Leben übergeht, noch als endliches Erkennen dasselbe in sich scheinenläßt, sondern in der absoluten Wahrheit ihrer selbst sich, das Moment ihrer Besonderheit oder des ersten Bestimmens und Andersseins, die unmittelbare Idee als ihren Widerschein, sich als Natur frei aus sich zu entlassen".

${ }^{26}$ Hegel, SL, s. 753, WL, s. 1582. Daß die Idee sich selbst frei entläßt, ihrer absolut sicher und in sich ruhend, um dieser Freiheit willen ist die Form ihrer Bestimmtheit ebenso schlechthin frei, - die absolut für sich selbst ohne Subjektivität seiende Äußerlichkeit des Raums und der Zeit.
} 


\section{REFERENCES:}

Aristotle, Posterior Analytics, tr. A. J. Jenkinson, In Complete Works of Aristotle, vol 1, (Ed.) Jonathan Barnes, Princeton University Press, 1991.

Beiser, Frederick: German Idealism: The Struggle against Subjectivism, 1781-1801, Cambridge, Harvard University Press, 2008.

Beiser, Frederick: Hegel, New York: Routledge, 2005.

Braßel, B. "Das Verhältnis von Logik und Natur bei Hegel" In Sich in Freiheit entlassen Natur und Idee bei Hegel, Ed. Helmut Schneider, Frankfurt am Main: Peter Lang GmbH, 2004, ss. 87-107.

Breidbach, O. Das Organische in Hegels Denken: Studie zur Naturphilosophie und Biologie um 1800, Würzburg, Konigshausen und Neumann Verlag, 1982.

Breidbach, O. "Zur Frage der Notwendigkeit einer Deduktion des Naturalen in der Perspektive der Hegelschen Logik" In Sich in Freiheit entlassen Natur und Idee bei Hegel, Ed. Helmut Schneider, Frankfurt am Main: Peter Lang GmbH, 2004, pp. 63-87.

Bronger, P. "Hegel's Library: The Newton Edition", In Hegel and Newtonianism, (Ed.) J. M. Petry, Stuttgart, Bad Cannstatt 1993, pp. 711-721

Buchdahl, G. "Hegel's Philosophy of Nature", The British Journal for the Philosophy of Science, V. 23, No: 3, 1972, ss. 257-266.

Burbidge, John W., Hegel's Systematic Contingency, London, Palgrave Macmillan, 2007.

Burbidge, John W.: "New Directions in Hegel's Philosophy of Nature" In Hegel: New Directions, Ed. Katerina Deligiorgi, Chesham, Acumen Publishing, 2006, ss. 177-193.

Burbidge, John W.: "Chemism and Chemistry", The Owl of Minerva, C. 34, No:1, 2002, pp. 3-17.

Croce, B. What is Living and What is Dead of the Philosophy of Hegel, tr. D. Ainslie, New York: Russell \& Russell Publishing, 1969.

Duhem, P. The Aim and Structure of Physical Theory, tr. P. P. Wiener, New Jersey: Princeton University Press, 1991.

Duhem, P. To Save the Phenomena: An Essay On The İdea Of Physical Theory From Plato To Galileo, Chicago, University of Chicago Press, 2015.

Engelhardt, D. "Grundzüge der wissenschaftlichen Naturforschung um 1800 und Hegels Spekulative Naturerkenntnis”, Philosophia Naturalis, V. 13, 1972, pp. 290-315.

Falkenburg, B. “How to Save Phenomena: Meaning and Reference in Hegel's Philosophy of 
Nature", In Hegel and the Philosophy of Nature, (Ed.) Stephen Houlgate, Albany, State University of New York Press, 1998, pp. 97-137.

Ferrini C., "Knowing Phenomena: The Quest for Truth in Hegel's Philosophy of Nature" In Sich in Freiheit entlassen Natur und Idee bei Hegel, (Ed.) Helmut Schneider, Frankfurt am Main: Peter Lang GmbH, 2004, pp. 125-157.

Ferrini, C., Being and Truth in Hegel's Philosophy of Nature, Hegel-Studien Vol. 37, Meiner, Hamburg, 2004b, pp. 69-90

Hahn, S. S. Contradiction in Motion: Hegel's Organic Concept of Life and Value, Ithaca: Cornell Unversity Press, 2007.

Halper, E. “The Logic of Hegel's Philosophy of Nature: Nature, Space and Time” In Hegel and the Philosophy of Nature, (Ed.) Stephen Houlgate, Albany, State University of New York Press, 1998, pp. 29-51.

Harris, E. "Hegel and the Natural Sciences" In Beyond Epistemology: New Studies in the Philosophy of Hegel, (Ed.) Frederick G. Weiss, The Hague: Martinus Nijhof, 1974, pp. 129154.

Harris, H. Hegel's Intellectual Development to 1807. In F. Beiser (Ed.), The Cambridge Companion to Hegel Cambridge: Cambridge University Press, 1993, pp. 25-51.

Hegel, G. W. F. Hegel's Philosphy of Nature: Being Part Two Of The Encyclopaedia Of The Philosophical Sciences (1830), (Ed.) Nicolin And Poggeler's Edition, tr. A. V. Miller, Oxford: Oxford University Press, 2004. (PN)

Hegel, G. W. F. The Encyclopaedia Logic: Part I of the Encyclopaedia of Philosophical Sciences with the Zusatze, tr. T. F. Geraets, W. A. Suchting, and H. S. Harris, Indianapolis, Hackett Publishing Company, Inc., 1991. (EL)

Hegel, G. W. F. The Science of Logic, tr. George di Giovanni, Cambridge, Cambridge University Presss, 2010. (SL)

Hegel, George Wilhem Frederich: Enzyklopädie der philosophichen Wissenschaften (1830): Gesammelte Werke 20, (Ed.) Friedhelm Nicolin \& Otto Pöggeler, Hamburg: Meiner Verlag, 1959. (G.W. 20)

Hegel, George Wilhem Frederich: Vorlesungen über die Philosophie der Natur I: Gesammelte Werke 24,1, (Ed.) Wolfganf Bonsiepen, Hamburg: Felix Meiner Verlag, 1959. (G.W. 24)

Hegel, George Wilhem Frederich: Wissenschaft der Logik I, Erster Teil, Baden, Suhrkamp Verlag, 1986, (WL)

Hyppolite, J. Genesis and Structure of Hegel's Phenomenology of Spirit, tr. Samuel Cherniak \& John Heckman, Illlinois, Northwestern University Press, 5. Edition, 2000,

Kant, I. Critique of Pure Reason, tr. Paul Guyer \& Allen Wood, Cambridge, Cambridge 
University Press, 1998.

Kolb, D. Critique of Pure Modernity: Hegel, Heidegger, and After, Chicago, University of Chicago Press, 1986.

Maker, W. "The Very İdea of the İdea of Nature or Why Hegel is not An İdealist" In Hegel and the Philosophy of Nature, (Ed.) Stephen Houlgate, Albany, State University of New York Press, 1998, pp. 1-29.

Marx, K. Selected Writings, (Ed.) David McLellan, Oxford University Press, 2th Edition, 2000.

Mense, A. "Hegel's Library: The Works on Mathematics, Mechanics, Optics and Chemistry", In Hegel and Newtonianism, (Ed.) J. M. Petry, Stuttgart, Bad Cannstatt 1993, pp. 669-711.

Monod, J. Chance and Necessity: An Essay on the Natural Philosophy of Modern Biology, tr. Austryn Wainhouse, New York: Vintage Books, 1972.

Neuser, W. "Die Naturphilosophische und Naturwissenschaftliche Literatur aus Hegels privater Bibliothek" Hegel und die Naturwissenschaften (Ed.) M. J. Petry, Stuttgart, Frommann Holzborg Verlag, 1987. pp. 479-501.

Neuser, W. Natur und Begriff: Zur Theoriekonstitution und Begriffsgeschichte von Newton bis Hegel, 2. Auflage, Weisbaden: Springer, 2017.

Quante, M. "Reason ... apprehended irrationally": Hegel's critique of Observing Reason. In Hegel's Phenomenology of Spirit: A Critical Guide, (Ed.) D. Moyar \& M. Quante, Cambridge: Cambridge University Press, pp. 91-111.

Petry, M. J. "Hegel's Philosophy of Nature: Recent Developments" Hegel-Studien, V. 23, 1998, pp. 30 3-326

Petry, M. J. "Hegelianism and The Natural Sciences: Some Current Developments and Interpretations” Hegel-Studien, V. 36, Hamburg, Felix Meiner Verlag, 2001, pp. 197-237.

Perty, M. J. "Foreword", In Hegel and Newtonianism, (Ed.) J. M. Petry, Stuttgart, Bad Cannstatt 1993. pp. X-XIV.

Pinkard, T. Hegel. A Biography. New York, NY: Cambridge University Press, 2000.

Pinkard, T. Hegel's Naturalism: Mind, Nature, and the Final Ends of Life, Oxford, Oxford University Press, 2012.

Popper, K. The Open Society And Its Enemıes Vol. II: The High Tide Of Prophecy: Hegel, Marx, And The Aftermath, London: Routledge, 1963.

Quante, M. "Reason apprehended irrationally": Hegel's critique of Observing Reason. In Hegel's Phenomenology of Spirit: A Critical Guide, (Ed.) D. Moyar \& M. Quante, Cambridge: Cambridge University Press, 2008, pp. 91-111. 
Rauch, L. "The Birth of Nature out of the Spirit of Logic” Hegel Jahrbuch, 1989, pp. 147-153.

Schelling, F. W. First Outlıne of A System of The Phılosophy of Nature, tr. Keith R.Peterson, Albany, State University of New York Pres, 2004.

Schmidt, K. J. "Die Logische Struktur der Natur", In Sich in Freiheit entlassen Natur und Idee bei Hegel, Ed. Helmut Schneider, Frankfurt am Main: Peter Lang GmbH, 2004, pp. 3163.

Stone, A. Petrified Intelligence: Nature in Hegel's Philosophy, Albany: State University of NewYork Press, 2005.

Taylor, C. Hegel, Cambridge, Cambridge University Press, 1975.

Verene, D. P. "Hegel's Nature", In Hegel and the Philosophy of Nature, (Ed.) Stephen Houlgate, Albany, State University of New York Press, 1998, pp. 209-227.

Wandschneider, D. "Nature and Dialectic of Nature in Hegel's Objective İdealism," Bulletin of the Hegel Society of Great Britain, V. 26, Autumn/Winter 1992, pp. 30-51.

Wandschneider, D. "Philosophy of Nature", tr. J. Edwards, In The Bloomsbury Companion to Hegel, (Ed.) Allegra de Laurentiis \& Jeffrey Edwards, London, Bloomsbury, 2013, pp. 103127

Washner, R. Zur Kritik der Hegelschen Naturphilosophie: Über Ihren Sinn im Lichte der heutigen Naturerkenntniss, Wien: Peter Lang, 1996.

Westphal, K. "Does Kant's Opus Postum Anticipate Hegel's Absolute Idealism?" In Kants Philosophie der Natur Ihre Entwicklung im "Opus postumum" und ihre Wirkung, Ed.Onnasch, Ernst-Otto, Berlin, Berlin, Walter De Gruyter, 2009, pp. 357-384.

Westphal, K. "Philosophizing about Nature: Hegel's Philosophical Project" In The Cambridge Companion to Hegel and Nineteenth-Century Philosophy, (Ed.) Frederick C. Beiser, Cambridge, Cambridge University Press, 2008, pp. 281-311.

Winfield, R. D. Conceiving Nature after Aristotle, Kant, and Hegel: The Philosopher's Guide to the Universe, New York, Palgrave Macmillan, 2017. 